\title{
Value Chains and Small Enterprise Development: Theory and Praxis
}

\author{
Edakkandi Meethal Reji \\ School of Management, Centurion University of Technology and Management, Odisha, India. \\ Email: rejimalayil@gmail.com
}

Received July 28 ${ }^{\text {th }}, 2012$; revised August $30^{\text {th }}$, 2012; accepted October $1^{\text {st }}, 2012$

\begin{abstract}
Drawing insights from the literature on global value chains and similar approaches, it is argued that adopting a value chain approach could help Micro and Small Enterprises (MSEs) to gain from the benefits of integration into global/local value chains and making them competitive. This paper reviews the theoretical perspectives in value chains and the emerging market development paradigm for small enterprise development. It provides evidences from experiences of practitioners and development agencies on the adoption of value chain approach as a facilitation tool for integrating MSEs into market. The evidence from literature suggests that adopting a value chain approach provides enormous opportunities for small enterprises to become competitive.
\end{abstract}

Keywords: Value Chain; Micro and Small Enterprises; Competitiveness

\section{Introduction}

Global value chain analysis offers a theoretical framework to understand the integration of firms into viable market system [1]. Global value chain studies, mostly dealt with the process of integration of developing country firms into the value chains of large firms in developed countries, examined the inter-firm relationships, governance and upgrading practices by which firms improves their competitiveness. It is well established that integration into global value chain helps the firms to improve their competitiveness. However, how far these new windows of opportunities are available to small producers is relatively unexplored. Integration of small scale producers into market is constrained by a host of factors: small size, limited access to resources, information, skills, technology and access to other business services. Integration of small scale producers into high value market is a topic of current interest. Value chain approach is widely used as a tool to facilitate this process of market integration. Unlike the traditional approaches to enterprise development, the value chain development emphasizes on facilitating market linkages, developing business services market and improving the environment in which enterprises operate. Although much works have been done to define and conceptualize the idea of value chain and similar programmes, the concept is still in its evolution. It is argued that adopting a value chain approach could help the small producers to benefit from integration into high value markets and improving their competitiveness. This paper examines how a value chain approach facilitate the process of integration of Micro and Small Enterprises (MSEs) in to high value market. The key sections of the paper covers: 1) concept of value chains; 2) approaches in integrating MSEs into market; 3) the current practices and emerging results from value chains and business service market development followed by summary of observations and conclusion.

\section{The Concept of Value Chains}

All firms are more or less embedded in network of firms [2]. The value chains provide a theoretical understanding for this network firm paradigm [3,4]. A value chain constitutes whole range of discrete, though interrelated, activities involved in the design, production and marketing of a product [5]. Various chain conceptualizations mentioned in the literature include: filiere approach [6], linkage approach [7], Porter's value chain [5], commodity/ global commodity chain [8] and the global value chain analysis [9]. All of them deal with the flow of products and services along the chain, relationships between firms and co-ordination of production chains.

The linkage approach and Porter's value chain constitute the two most influential chain conceptualizations. The linkages approach, proposed by Hirschman [8] argues that investment in a firm produces demand effects that induce subsequent investment (backward linkages) by input suppliers. Porter [5] used the concept of value chain to explain firm's competitive advantage within an 
industry. Porter used the concept to include all of the activities that a firm performs to design, produce, market, deliver and support its product. The filiere approach originally dealt with the vertical integration of firms in agriculture trade [6]. It focused to map the actual commodity flows and to identify the agents and activities within a filiere (chain), which is viewed as a physical flow chart of commodities and transformations.

During 1990s, the early filiere analysis was modified into a more comprehensive analytical framework called Global Commodity Chain (GCC) analysis. A global commodity chain is defined as a set of transnational interorganisational linkages that constitute the production, distribution and consumption of a commodity [10]. A major difference between these two approaches is that the filiere approach focused specifically on agricultural commodities, but the GCC analysis focused on manufacturing firms in which economic integration goes beyond international trade in raw materials and final products. The GCC analysis has emerged as a framework to map and analyse the spatially dispersed and organizationally complex production networks that are an important aspect in economic globalization [11].

The global commodity chain analysis was subsequently replaced with a more general term, global value chain (GVC) analysis [8,12]. The GVC analysis mainly focused on the governance structure of value chains, where the lead firms, the governors of value chains have the capability and power to define and impose the parameters of contracts and subcontracts in their supply chain. One of the important distinctions of global value chain analysis from other chain conceptualizations, as referred above, is its emphasis on the typology of governance relations in value chains. Gereffi [9] identified two different governance types: "buyer driven" and "producer-driven". The buyer-driven chains are led by large retailers, branded marketers and trading companies; while producer driven chains are led by capital and technology-intensive firms. Building on these two concepts, Gereffi and Sturgeon [13] later developed a typology of governance relations consisting of five governance categories involving: arm's length, modular, relational, captive and hierarchical, that has implications on governance structure of the value chains.

Another key concept widely used in GVC analysis is upgrading. Humphrey and Schmitz [14] developed four typologies of upgrading that involves: process upgrading (enhanced efficiency), product upgrading (higher unit value through increased sophistication), functional upgrading (increasingly concentrating on skill content), and inter-chain/sector upgrading(moving up to a more profitable GVC in another sector), that have significant impact on the competitiveness of the firms in the value chain. The GVC analysis provided new practical insights on governance structures and upgrading opportunities of the firms in the value chains of textiles and clothing [9], fresh fruits and vegetables [15], commodities such as wooden furniture [16] and leather products [10].

\section{Approaches in Integrating MSEs into Viable Market System}

\subsection{Value Chain Development}

In recent years, the concept of value chain is widely used as a facilitation tool for integrating small enterprises into high value market. The value chain development programs focus on improving the competitiveness of the industry/sector in which the firm operates [17]. The core of the value chain approach is the recognition that, the strategies for enterprise development needs to focus on the entire value chain rather than focusing on a particular aspect of provision of credit or input supply. The value chain approach emphasizes on identifying the opportunities for and constraints to industrial growth by considering the value chain actors (firms), linkages among firms, supporting markets, end markets, and the business enabling environment at all levels [18]. The value chain approach also emphasizes on other factors that influence the chain's performance, including access to and the requirements of terminal markets, the legal, regulatory and policy environment, and the availability and quality of support services such as financial services, equipment manufacture and repair, business management services and information technology.

Value chain development is fundamentally about strengthening market relationships so that businesses work better together to compete more effectively in the global market [19]. Kula et al. [18] provides a step-by step guide to intervention design for achieving competitiveness that benefits the poor: first industries are selected with potential for competitiveness, and then a value chain analysis is carried out; a strategy is developed to improve competitiveness and achieve an equitable distribution of benefits; an action plan is devised to achieve this strategy; and finally a system of performance monitoring and impact assessment is devised to evaluate the effectiveness of value chain interventions.

It is argued that integration into value chains helps the small firms to: 1) increase the efficiency of its internal operation; 2) develop inter-firm linkages that reduce transaction costs; and 3) upgrade along the value chain (introduce product branding, new products, and improved version of existing products in the market faster than the rivals) [20]. Studies also reveal that, by forging extensive collaborative ties between the firms facilitate: sharing of knowledge, technologies and inputs [21]; develop greater responsiveness to global demands [22]; and attain greater export levels as a result of collective efficiency [23] and 
improving competitiveness.

\subsection{Business Service Market Development}

There is increasing recognition that MSEs need specific business development services (BDS) to reach higher value markets and/or improving competitiveness [24]. However, the MSEs in general are constrained to access these business services. An important component of the most of the value chain development programs is the facilitation of BDS market. BDS refers to the wide range of services used by entrepreneurs to help them operate efficiently and grow their businesses [25]. Formerly known as "non-financial services" the field originally concentrated on providing training, consulting, and other services that addressed the internal constraints of enterprises - their lack of education and technical capacity. The SEEP Guide to Business Development Services identified seven BDS categories that include: market access, input supply, technology and product development, training and technical assistance, infrastructure, policy/advocacy and alternative financing mechanisms. More recently, the BDS field has grown to include marketing services and information resources that help firms gain access to services usually enjoyed only by larger firms.

BDS market development initiatives are increasingly becoming part of broad development initiatives rather than stand-alone programs for provision of BDS services to individual entrepreneurs [26]. The BDS market development aim to improve sector competitiveness, develop the private sector, and help micro-enterprises to compete in global markets. The BDS market development proposes a new vision for success, one that looks like a healthy, private-sector, business services market: numerous, competitive BDS suppliers who sell a wide range of BDS commercially, to large numbers and types of small enterprises [25].

The BDS market development process start by understanding the existing supply of BDS from the private sector, donor supported programs and government, and the market failures that lead to a gap between supply and demand for services. The goal of market development interventions, thus, is to overcome these market failures and take advantage of opportunities to expand the service market for small enterprises. The desired result is that numerous small enterprises buy the BDS of their choice from a wide selection of products offered (primarily) from unsubsidised, private sector suppliers in a competitive and evolving market.

McVay and Miehlbradt [27] provide a summary of various strategies used to promote business services to MSEs. Some of these strategies include: use of vouchers and matching grants, providing information to consumers that aim to expand the demand for BDS by making small enterprises aware of available services and potential be- nefits, help small enterprises overcome diseconomies of scale in purchasing BDS by enabling them to purchase services in groups by operating in clusters and networks, create or expand BDS embedded within business relationships between them and other firms, build the capacity of new or existing BDS suppliers to profitably serve small enterprises through technical assistance, comercializing of new products through existing suppliers by assisting with product development, market testing and initial marketing of new products.

In response to MSE's demand for business services, some common trends in delivery of BDS are emerging. Some of these common BDS practices include: common sector-common services; information and communication technologies; media sector services; and BDS finances [25]. It is found that majority of the programmes in BDS have a sector focus. For example, programmes that targeting horticulture sector focuses on establishing sub-contracting, technical assistance to grow appropriate crops, micro-irrigation, organizing producer association/ groups, access to inputs and price information [28]. Similarly, the BDS programs promoting animal husbandry focuses on providing veterinary services at village level through paravets and on improving infrastructure for marketing of fresh products [29]. Programs promoting handmade products (crafts) have a focuses on linking the producers with international/national markets through organizing trade shows, product development and design, continuous quality improvement, association and group development, ensuring adequate supply of inputs, supplies and funds [30].

\section{Value Chain/Business Service Market Development in Practice}

\subsection{The Farm Implements and Tools (FIT) Program}

The FIT program is an example of successful private sector supply of BDS in Uganda [31]. The Program has designed and commercialized a range of innovative services using an action research methodology. This methodology has tested both the products and commercial delivery channels that include enterprise visits and commercial training facilitations. The FIT program identified a demand from small business owners to learn from others and experimented with national enterprise visits of MSE groups to meet their counterparts in other parts of the country. Enterprise visits have emerged as a recognized and effective tool for networking, developing new markets and exchanges of technologies and skills for MSEs. The FIT program had developed and tested two training methodologies to help MSEs undertake practical marketing and demand-based product development. These products were tested first through traditional, donor-sup- 
ported training channels and subsequently sold to commercial training businesses through training of trainer courses in East Africa. These two products and another training product (Grassroots Management Training) were eventually sold into the private sector where they were modified and adapted to meet to the demands of the training market.

Another example of successful private sector supply of BDS under FIT program involve a participant of the ILO sponsored training program called Improve your Business Training, who offered fee based training to [her] fellow enterprises. The commercial small enterprise radio program initiated by FIT provides market information and promote interaction among small enterprises and BDS suppliers. They have been instrumental in eliminating policy bottlenecks and opening markets for milk traders and fishermen, increasing safety and sanitation in physiccal markets, and reducing electrical and telecommunications costs. They reach over 300,000 listeners.

\subsection{Shea Kernel Value Chain, Mali}

Action for Enterprise (AFE), with USAID funding, is developing the Shea subsector in Mali by improving its access to export markets, which benefit a large number of rural women who harvest and process Shea nuts [32]. Shea butter is processed from nuts, which grow on indigenous trees in semiarid conditions. A major share of Shea is consumed in Mali. The exported Shea is mostly traded in kernel form and processed into butter by four lead industrial processors, mainly in Europe, who dominate this high-demand market. These buyers fill only 10 percent of their annual kernel requirements from Mali because of poor product quality, high transportation and border crossing costs, and unreliable delivery.

The project team started by exploring the potential for exporting higher value Shea butter, which included market research and development, Shea butter quality assessment, and assessment of constraints to market penetration. The project then attempted to induce exporters to invest in production and supply chain improvements that would result in a more marketable product. These activeties included facilitating contact with international buyers, promoting Mali Shea butter and suppliers via a website, building the capacity of exporters to respond to buyers with quotes and professional samples, and troubleshooting logistical (packaging and transportation) issues, many of which involved sharing costs with exporters and buyers.

In view of the comparatively poor quality of Mali's Shea butter and high cost logistics, the opportunities for exporting high quality Shea butter went mostly to neighboring countries, notably Ghana. However, opportunities for exporting high quality Shea kernels materialized through contact with European buyers and were devel- oped as a means of promoting quality improvements to the raw material for Shea butter and increases in rural incomes of Shea kernel suppliers. In addition, exporters viewed investments to improving Shea kernel quality as more manageable and less risky in view of the significance of the market opportunity. At this point, the project team helped exporters improve their supply chain by improving the linkages between exporters and their suppliers, and between suppliers and women Shea gatherers. The project team helped exporters organize their suppliers, for example, by carving out territory for each one to cover. AFE developed training materials and trained exporters to use these materials in training their Shea traders. Some topics included were: Shea quality criteria, operational procedures for procuring and handling Shea kernels, financing policies and arrangements, attracting Shea gatherers, and communicating with and providing technical guidance to Shea gatherers. The project also developed and cost-shared new types of promotional activities, such as radio spots to inform Shea gatherers of the opportunity and quality concerns. Costs were kept low and techniques simple so that exporters could easily replicate the strategies once the project ended. According to project management, building these linkages required steady attention to the expectations and issues of market players in order to coax the process forward in a sustainable manner. This meant finding a balance between too much and too little involvement. For example, when project staff learned that both the importer and the exporter were looking for communication from each other and not getting it, project staff coached each party to take the initiative to send an e-mail, rather than transmitting the information themselves. Although this coaching role takes longer than more direct involvement, it establishes more durable market linkages.

\subsection{Honey Value Chain in Muzaffarpur, India}

This is a Ford foundation assisted project that operates in 200 villages in Muzaffarpur region in India [33]. The project focused on value chain development of honey. Implemented by the EDA Rural System, an enterprise consulting firm, the project assisted the bee-keepers in the regions in bee-keeping activities. The EDA Rural conducted an initial value chain assessment of the sector which revealed that the bee-keepers lacked any knowledge of scientific bee-keeping, honey extraction methods, disease control, quality control etc. The initial activities included mobilization of bee-keepers in to associations, training on basic bee-keeping, and the development of bank and market links including promoting professional marketing agents. The other activities included; forming the bee-keepers federation, promoting the strategic alliance between a local co-operative marketing institutions known as Timul, the development of website, efforts to 
reduce tax on honey trade and publishing the bee-keepers directory. Over a period of three years 42 bee-keepers associations were formed with 1484 members from 128 villages. The associations' members have a total of 82,000 bee-hives with an annual production of over 4000 MT. EDA also worked to create viable market linkage working with Timul and Dabur. The result is that honey is being marketed through the network of Timul a co-operative marketing institution, and Dabur India. A network of traders called Professional Marketing Agents, were also created for marketing of honey produced by the bee-keepers. The EDA team also helped to establish new suppliers of bee-hives, bee-broods and foundation sheets so that the bee-keepers could obtain the supplies they needed on time. Two honey processing units were also established. A state level federation of bee-keepers was formed in April 2005 to help the bee-keepers identify and act on issues hindering the growth of their business, and to act as a catalyst for the industry. With the guidance from EDA, this federation has undertaken several activities including ensuring better return on honey, training, developing the market and strengthening bank linkages, supplying inputs to bee-keepers and policy advocacy such as dealing with sales tax issue, the publication of bee-keepers directory, and audit and capacity building services for the associations.

\section{Value Chains and Small Enterprise Development: Emerging Results}

\subsection{Market Access}

A vast literature on value chains and BDS market development provide evidences on small firm's access to market. Humphrey and Alemann [34] have reviewed several MSE value chain interventions across different countries. Some of these interventions focus on establishing business-to-business linkages along the value chain, while others look at improving the broader business environment in which the value chain operate. They found that value chain interventions that are oriented towards business-to-business linkages typically employed one or four methods to improve chain performance. These include: 1) identifying and working with weak links within value chains that undermine the performance of value chain as a whole; 2) improving flows of resources and knowledge along the chains; 3 ) improving the efficacy of linkages between chain actors; and 4) developing new alternate linkages in the value chains. It was found that interventions oriented towards the wider business environment focuses predominantly on mobilizing stakeholders to engage with regulators and government.

Several organizational forms and business models have emerged for facilitating MSE's integration into market. Jenkins et al. [35] have identified six types of mechanism by which large companies are supporting business linkages and SME development. These mechanisms include: partnerships along individual company value chains; groups of companies in the same industry sector or location working collectively together; traditional trade and industry associations enhancing their capacity to better serve SMEs; joint public-private financing mechanisms; dedicated small enterprise support centers; and multi-stakeholder public policy structures.

A study by Harilal et al. [36] examined whether an expanding global market provides opportunities to enhance the livelihoods of small cashew farmers in India and increase employment in the processing industry. Their analysis indicates that concentration and consolidation in the power of retail giants tend to drive down the terms on which in-country suppliers and other even less powerful actors engage in the production and processing of cashew nuts.

Harper [37] provides several examples of fully integrated value chains that demonstrate even the smallest producers can be linked to modern markets in ways which are profitable for all parties. These case studies invariably show that if rightly built, value chains can include and benefit poor producers by offering them an opportunity to piggy back on growth of demand in distant locations, which small producers can never reach on their own.

Deka and Kumar provide the experience of PRADAN, a national level NGO in India working on development of small holder poultry in Madhya Pradesh [38]. PRADAN started work by introducing incremental changes in the existing backyard poultry systems through supply of cockerels, improved dual purpose birds, marketing support and mobilization of poultry producers (comprising of women from tribal and dalit families) into Self Help Groups (SHGs). Subsequently, PRADAN motivated these SHGs to organize themselves into a co-operative called Kesla Poultry Cooperative Society. The co-operative has set up four state of the art Sukhtawa Chicken outlets in Bhopal where chicken are sold live and are processed in the machine in front of the consumer. PRADAN provides a crucial role in terms of support, capacity building, exchange and providing linkages, research, etc. In their study [38], it was found that formation of the Kesla Poultry Co-operative Society has successfully linked small poultry producers to fast growing broiler markets by building a transparent collective, filling skill gaps, addressing production variables, providing inputs services and networking for set-up costs.

International Development Enterprises (IDE) Nepal is helping small and marginal farmers in remote rural areas to increase production from subsistence to commercial levels [39]. IDE focused on developing commercial markets for agricultural inputs, in particular micro-irrigation. 
In this effort, IDE had developed and comercialized comprehensive input packages appropriate for smaller-scale farmers and linked these farmers with buyers to help them grow and sell higher value vegetable crops.

The Tripple Trust Organisation (TTO) in Africa is strengthening the links between spaza owners (small retail shops) and product manufacturers and wholesalers who are interested in penetrating the township market [40]. TTO is assisting spaza owners in forming a network called Shop-Net, which strengthens spaza shops' position in the grocery supply chain. Shop-Net provides three basic benefits to spaza owners: 1) membership in a voluntary buying group to purchase stock collectively and secure discounts with local wholesalers; 2) access to business support services-costing, pricing, store management, and customer relations; and 3) access to linkages with suppliers, manufacturers, wholesalers, and other trading partners.

\subsection{Access to Business Services}

There is increasing evidences on MSE's access to a variety of business services as a result of inclusion in value chains. Kashyap [41] describes the experience of organising Gram Shree Mela, an exhibition cum marketing event targeted for the rural producers in India. These exhibitions helped the participants to directly interact with urban consumers and sell their products. In addition, the participating groups received free marketing advice, and serious effort was also made to bring producer and consumer in to direct contact thereby eliminating the ubiquitous middleman.

Manaktala [42] reports experience of International Development Enterprise (IDE) in India. IDE is reaching over 450,000 poor farmers with micro-irrigation systems and other agricultural services through 2000 profitable service providers.

A study by the International Labour Organization [43] in Thailand and Vietnam provide information on various business models for BDS delivery that include: 1) fee for service; 2) commission basis; 3) through business relationships; and 4) through the business environment. It was found that sales services were typically provided on a commission basis. The channel through which the widest variety of services was delivered was business relationships. Services delivered through this channel included training, marketing, product design, and market information. Some types of business information were also offered through the media and customers. The study also shows that even the smallest businesses obtain business services through private sector channels. The ILO study [43] also cites several examples of embedded business services found in Vietnam furniture industry. In Vietnam, many furniture showrooms in Hanoi sell furniture sourced from rural small scale producers. Some of these showrooms provide market information and product designs to their suppliers; one of them prepares design drawings when ordering furniture from rural producers. These services help rural producers stay in touch with changing urban market trends and the showrooms embed the cost of this service in the commission and mark-up it receives on sales and orders.

In Kenya, Tototo Home Industries is providing business services to a large number of women's groups [44]. In association with World Education, Tototo Home Industries introduced an innovative participatory business training program focused on three specific themes: profit, regular return and financial records. It employed several participatory methods to engage the trainees. The overall impact of the training program reflected on the improvement in financial performance of the member's group business.

The FIT program in Ghana and Kenya facilitate commercial BDS market for MSEs [45]. It facilitated series of exhibitions and workshops with farmer groups and MSEs in a process of 'participatory technology development' with opportunities for entrepreneurs to show case their products and interact with a large number of potential customers. The qualitative assessment of the FIT program revealed that the participating MSEs were able to improve technical skills and knowledge about improved equipment, improved linkages with suppliers, received ideas for new improved products, able to improve their management skills, particularly in customer relations, record keeping and employee relations.

\section{Conclusions}

The various chain conceptualizations, particularly the global value chain analysis provide a framework to map and analyze the spatially dispersed and organizationally complex production networks that are an important aspect of economic globalization. The studies in global value chain analysis examined market integration of firms in terms of inter-firm relations, governance relations and upgrading practices. It is well recognized that integration into global value chain improves firm's competitiveness. The integration of small firms into global value chains is an emerging area of research. In recent years, there is an increasing effort in linking small producers into high value market.

Value chain development and BDS market development constitute two widely used approaches in integration of small producers into market. While value chain development emphasizes on strengthening market relationships, the BDS market development aims to improve sector competitiveness through creating a viable market for business services. Most of the studies dealt with value chain business models and experiences of agencies promoting value chain development. Experiences of pro- 
moting pro-poor value chain suggest that integration small producers in to global/local value chains provide opportunities for them in improving their competitiveness.

An important outcome of the value chain development and BDS market development, as revealed by several studies, is the improved market access for small producers. This market access is made possible by strengthening of inter-firm relationships, fostering collective action and creating an enabling business environment. Several models of integration have emerged. In most cases the small producers are facilitated to work in groups/producers' organization. Another commonly found linkage model is the initiative of a lead firm.

Developing a market for business services is an important aspect of integration of small producers into the market. In most cases, small producer's access to business services is made possible through inter-firm linkages and developing market for business services. Unlike the traditional approach to provision of BDS involving subsidized training or market support, the BDS market development emphasize on private provision of business services. The emphasis is on building capabilities of the BDS providers to extent cost effective BDS to small producers. A key learning from BDS market development and value chain development is that even the smallest producers will also be able to benefit from market integration, by creating appropriate models of market integration.

\section{Acknowledgements}

The author gratefully acknowledges the support and encouragement received from Dr. Samapti Guha, Dr. Satyajit Majumdar and Dr. Bino Paul, Professors in Tata Institute of Social Sciences (TISS), Mumbai, India, for preparing this paper. The author also acknowledges the constructive suggestions from the anonymous referees for revising the paper.

\section{REFERENCES}

[1] G. Gereffi, J. Humphrey, R. Kaplinsky and T. J. Sturgeon, "Introduction: Globalisation, Value Chain and Development,” IDS Bulletin, Vol. 32, No. 3, 2001, pp. 1-12. doi:10.1111/j.1759-5436.2001.mp32003001.X

[2] F. Belussi and F. Arcangeli, "A Typology of Networks: Flexible and Evolutionary Firms," Research Policy, Vol. 27, No. 4, 1998, pp. 15-28. doi:10.1016/S0048-7333(98)00074-2

[3] H. Thorelli, "Networks: Between Markets and Hierarchies," Strategic Management Journal, Vol. 7, No. 1, 1986, pp. 37-51. doi:10.1002/smj.4250070105

[4] W. W. Powel, "Neither Market nor Hierarchy: The Network Forms of Organization,” In: B. M. Straw and L. L. Cummings, Eds., Research in Organizational Behavour,
JAI-Press Inc., Greenwich, 1990, pp. 295-336.

[5] M. E. Porter, "Competitive Advantage: Creating and Sustaining Superior Performance,” The Free Press, New York, 1985.

[6] P. Raikes, F. M. Jensen and S. Ponte, "Global Commodity Chain Analysis and the French Filière Approach: Comparison and Critique,” CDR Working Paper No. 3, Centre for Development Research, Copenhagen, 2000.

[7] A. Hirschman, "The Strategy of Economic Development," Yale University Press, New Haven, 1958.

[8] G. Gereffi and M. Korzeniewicz, "Commodity Chains and Global Capitalism,” Praeger, Westport, 1994.

[9] G. Gereffi, "International Trade and Industrial Upgrading in the Apparel Commodity Chain,” Journal of International Economics, Vol. 48, No. 1, 1999, pp. 37-70. doi:10.1016/S0022-1996(98)00075-0

[10] M. Korzeniewicz, "Global Commodity Networks and the Leather Footwear Industry: Emerging Forms of Economics Organization in Postmodern World,” Sociological Perspectives, 1992, Vol. 35, No. 2, pp. 313-327. doi:10.2307/1389381

[11] J. Bair, "Global Capitalism and Commodity Chains: Looking Back, Going Forward,” Competition and Change, Vol. 9, No. 2, 2005, pp. 153-180. doi:10.1179/102452905X45382

[12] J. Humphrey and H. Schmitz, "Governance and Upgrading: Linking Industrial Cluster and Global Value Chain Research,” Working Paper No. 120, Institute of Development Studies, Brighton, 2000.

[13] G. Gereffi, J. Humphrey and T. Sturgeon, "The Governance of Global Value Chains," Review of International Political Economy, Vol. 12, No. 1, 2005, pp. 78-104. doi:10.1080/09692290500049805

[14] J. Humphrey and H. Schmitz, "How Does Insertion in Global Value Chains Affect Upgrading in Industrial Clusters?” Regional Studies, Vol. 36, No. 9, 2002, pp. 10171027. doi: $10.1080 / 0034340022000022198$

[15] C. Dolan, J. Humphrey and C. Harris-Pascal, "Horticultural Commodity Chains: The Impact of the UK Market on the African Fresh Vegetable Industry,” IDS Working Paper No. 96, Institute for Development Studies, University of Sussex, 1999.

[16] R. Kaplinsky, M. Morris and J. Readman, “The Globalization of Product Markets and Immersing Growth: Lessons from South African Furniture Industry," World Development, Vol. 30, No. 7, 2002, pp. 1159-1177. doi:10.1016/S0305-750X(02)00029-3

[17] L. M. Jones, "Value Chains in Development: Emerging Theory and Practice," Practical Action Publishing, Rugby, 2011.

[18] O. Kula, J. Downing and M Field, "Value Chain Programs to Integrate Competitiveness, Economic Growth and Poverty Reduction,” Small Enterprise Development, Vol. 17, No. 2, 2006, pp. 23-36. doi:10.3362/0957-1329.2006.017

[19] A. O. Meihlbradt and M. McVay, "From BDS to Making Markets for the Poor, the 2005 Reader,” International Labor Organization, Turin, 2005.

[20] R. Kaplinsky, “Globalization and Unequalisation: What 
Can Be Learned from Value Chain Analysis,” Journal of Development Studies, Vol. 32, No. 7, 2000, pp. 117-146. doi:10.1080/713600071

[21] M. Storper, “The Regional World: Territorial Development in a Global Economy,” Guildford Press, New York, 1997.

[22] L. Canina, C. A. Enz and J. S. Harisson, “Agglomeration Effects and Strategic Orientations: Evidence from US Lodging Industry,” Academy of Management Journal, Vol. 48, No. 4, 2005, pp. 565-577. doi:10.5465/AMJ.2005.17843938

[23] H. Schmitz, "Collective Efficiency: Growth Path for Small Scale Industry,” Journal of Development Studies, Vol. 31, No. 4, 1995, pp. 529-567. doi:10.1080/00220389508422377

[24] R. Hitchins, E. David and A. Gibson, "Making Business Service Markets Work for the Poor in Rural Areas," Springfield Centre, United Kingdom Department for International Development, London, 2004.

[25] M. McVay and A. O. Miehlbradt, "Developing Commercial Markets for BDS: Can This Give the Scale and Impact We Need?” Second Annual Seminar, Turin, 10-14 September 2001, pp. 1-80.

[26] Donor Committee of Enterprise Development, "Donor Committee Guiding Principles, 2001 SEEP Guide to Business Development Services and Resources,” Small Enterprise Education and Promotion Network. www.seepnetwork.org/bdsguide.html

[27] M. McVay and A. O. Miehlbradt, "Developing Commercial Markets for Business Development Services, BDS Update-2004,” International Labour Organization, Turin, 2004.

[28] D. Knopp, "Recommended Performance Assessment for Subsector Development, Kenya Business Development Services Program,” Deloitte Emerging Markets/Action for Enterprise/ACDI/VOCA/Land O'Lakes-United States Agency for International Development, Washington DC, 2002.

[29] K. Abdullayev, "Cluster Approach to Business Services (CABS) Program in Rural Azerbaijan,” United States Agency for International Development, Washington DC, 2003.

[30] L. Jones and P. Shaikh, "From behind the Veil: Access to Contemporary Markets for Homebound Women Embroiderers in Pakistan,” Mennonite Economic Development Associates and Entrepreneurship Career Development Institute, Pakistan, 2004.

[31] M. Hileman and J. Tanbun, "The Wheels of Trade: Developing Markets for Business Services,” Intermediate Technology Publications, Rugby, 2000.

[32] F. Lusby and E. Derks, "Shea Kernal Value Chain,” Small Enterprise Development, Vol. 17, No. 2, 2006, pp. 36-46. doi:10.3362/0957-1329.2006.018

[33] A. Kumar, "Honey in Muzaffarpur,” In: M. Harper, Ed., Inclusive Value Chains: Linking Small Producers to Modern Markets, World Scientific, Chennai, 2009, pp. 176-
194.

[34] J. Humphrey and L. Navaz-Aleman, "Value Chains, Donor Interventions and Poverty Reductions: A Review of Donor Practice,” Institute of Development Studies, Sussex, 2010.

[35] B. Jenkins, A. Akhalkatsi, B. Roberts and A. Gardiner, "Business Linkages: Lessons, Opportunities, and Challenges,” International Business Leaders Forum, and the Kennedy School of Government, Harvard University, Cambridge, 2007.

[36] K. N. Harilal, K. Nazneen and J. Jeyaranjan, "Power in Global Value Chains: Implications for Employment and Livelihoods in the Cashew Nut Industry in India,” International Institute for Environment and Development, London, 2006.

[37] M. Harper, "Inclusive Value Chains in India: Linking the Smallest Producers with Productive Markets," World Scientific Publishers, Chennai, 2009.

[38] H. K. Deka and K. Anish, "Making Modern Poultry Work for the Poor: An Example of Co-Operative Development from Madhya Pradesh, India,” South Asia Pro-Poor LiveStock Policy Programme (SA PPLP), a Joint Initiative of NDDB and FAO, 2009.

[39] R. Bista, "Making BDS Providers Work for the Smallholder Farmers in Nepal: IDE Lessons Learned and Insights Gained,” International Development Enterprises, Small Enterprise Education \& Promotion Network/Practitioner Learning Program-United States Agency for International Development, Washington DC, 2004.

[40] M. Bear, "Making Retail Markets Work for the Poor: Why and How Triple Trust Organization Decided to Intervene in the Spaza Market," SEEP, Washington DC, 2005.

[41] P. Kashyap, “Marketing Rural Products in India,” Small Enterprise Development, Vol. 2, No. 2, 1991, pp. 51-55. doi:10.3362/0957-1329.1991.020

[42] S. Manaktala, "Creating New Markets for the Poor with Micro Irrigation Technologies in Maharashtra, India: Annual Progress Report,” International Development Enterprises (IDE), 2002.

[43] G. Anderson, "The Hidden MSE Service Sector-Research into Commercial BDS Provision to Micro and Small Enterprises in Vietnam and Thailand," Donor Committee Conference on Business Services for Small Enterprises in Asia: Developing Markets and Measuring Performance, 2000. www.sedonors.org (BDS materials)

[44] M. Walsh, K. Kevin and N. Candance, "A Case for Business Training with Women'S Groups,” Small Enterprise Development, Vol. 2, No. 1, 1991, pp. 13-19. doi:10.3362/0957-1329.1991.003

[45] J. Tanburn, "Towards Success: Impact and Sustainability in the FIT Program," Small Enterprise Development, Vol. 7, No. 1, 1996, pp. 42-51. doi:10.3362/0957-1329.1996.005 